\title{
Some Sero-biochemical Reference Values of Working Donkeys (Equus asinus) from the Sudan
}

\author{
Nabaa Kamal Al shafei ${ }^{1 *}$, Shadia Mohamed Ahmed ${ }^{2}$ and Abdalla Mohamed Ibrahim ${ }^{3}$ \\ ${ }^{1}$ Department of Biochemistry, College of Veterinary Medicine, University of Bahri, Khartoum, Sudan \\ ${ }^{2}$ Department of Medicine, College of Veterinary Medicine, University of Bahri, Khartoum, Sudan
}

${ }^{3}$ Department of Parasitology, College of Veterinary Medicine, University of Bahri, Khartoum, Sudan

\begin{abstract}
Little biochemical information is available on donkeys, although donkey is one of the regular patients that regularly come to the veterinary clinics in the Sudan. Moreover, many researchers use the donkey as experimental animals. The aim of the present study is to avail data on sero-biochemical reference values of working donkeys in the Khartoum State. Ninety nine healthy adult male donkeys, 3-26 years of age, were employed in this study. Blood for serum was collected from the jugular vein of the examined animals. All sera were subjected to appropriate chemical analysis procedures and determined the following values: $0.07 \pm 0.21$ for creatinine, $13.81 \pm 3.43$ for urea, $0.73 \pm 0.53$ for uric acid, $164.84 \pm$ 38.88 for potassium, $5.88 \pm 1.95$ for calcium, $3.13 \pm 1.09$ for sodium and1.69 \pm 0.61 for phosphorus which were in the range of that reported for other serum levels for other donkey breeds (Sudanese donkey, Ethiopian donkey, Saudi Arabia donkey and Burkina Faso donkey). However, there are exceptions: Creatinine, urea, sodium and uric acid. This study showed that our results in comparison of traditional biomarkers reference ranges are similar. Therefore, more studies are needed to determine others parameters for donkeys and others country-specific parameters for donkeys.
\end{abstract}

Keywords: Biochemical parameters; Sudan; Working donkeys

\section{Introduction}

Determination of the main haematological and serum biochemical parameters of animals helps veterinarians to confirm clinical diagnosis, estimate the severity of cases, administer appropriate treatment, and evaluate treatment outcomes [1]. To interpret data correctly, the results obtained in the laboratory must be compared with values corresponding to the reference values of clinically healthy animals, which serve as a guide to the clinician in evaluating parameters [2]. Equines, particularly donkeys, have been totally neglected despite their prominent role in both the rural and urban societies of the country. Hence research on donkeys has been lagging far behind other domestic species. Blood and serum reference values of clinically healthy animals serve as a guide to the clinicians evaluating clinical findings. Therefore, research on donkeys that focuses on health and welfare should be strengthened [3]. Donkeys contribute considerably to the agricultural economy of the third world mainly through their transport role; carrying loads, goods, water, and other forms needed by man. In other places, the donkey is used for farming and thus has become a necessity without which life would be very difficult to those people especially in the rural areas where donkeys stand as a great asset for the farmers and families. Donkeys are mainly used for draught power and transport, they are however, managed on semi intensive system [4]. The renewed interest in donkeys' health and welfare has been demonstrated by studies carried out to establish baseline data on both hematological and biochemical variables in the blood of adult donkeys [5]. With the exception of the work, no or very few works have been undertaken in relation with indigenous Equus asinus donkey in Sudan [5]. Although disorders in mineral metabolism are also important in donkeys, there is an almost complete lack of information on serum variables of mineral metabolism in that species. Donkeys are becoming popular as pets, and there is an increasing demand for medical care for them. We thus analyzed blood samples from ninety nine apparently healthy donkeys to determine baseline data regarding some biochemical variables in the blood which may help in clinical diagnosis of diseases in this animal species.

\section{Materials and Methods}

\section{Study area}

Khartoum State: The capital of the Sudan including its three Districts namely: Khartoum, Khartoum North and Omdurman.

\section{Study population}

A total of 99 apparently healthy adult male donkeys aging 3-26 years were sampled between January and July, 2013.

\section{Samples}

Blood for serum was collected from the jugular vein of the examined animals in plain vacutainers. Care was taken not inflict undue stress on the donkeys, or contaminate the samples. Samples were allowed to coagulate at room temperature for 30 minutes, then centrifuged at 3000 revolutions per minute (RPM) for 10 minutes. The clean serum from each sample was aspirated carefully by a pasture pipette, and transferred into dry, sterile, and labeled cryo-tubes and stored at $-20^{\circ} \mathrm{C}$ until needed.

\section{Biochemical examination}

All sera were subjected to appropriate analytical procedures to determinate different biochemical parameters. Urea was determined by using the urease-modified Berthelot enzymatic reaction following the procedure outlined by Seri, et al. [6] Uric acid was enzymatically

*Corresponding author: Nabaa Kamal Al shafei, Department of Biochemistry, College of Veterinary Medicine, University of Bahri, Khartoum, Sudan, Tel: +249 122410042; E-mail: nabaak@yahoo.com

Received: April 28, 2015; Accepted: August 20, 2015; Published August 22, 2015

Citation: Al shafei NK, Ahmed SM, Ibrahim AM (2015) Some Sero-biochemical Reference Values of Working Donkeys (Equus asinus) from the Sudan. Biochem Anal Biochem 4: 202. doi:10.4172/2161-1009.1000202

Copyright: (c) $2015 \mathrm{Al}$ shafei NK, et al. This is an open-access article distributed under the terms of the Creative Commons Attribution License, which permits unrestricted use, distribution, and reproduction in any medium, provided the original author and source are credited. 
determined by the quantitative determination method of uric acid according to the procedure described by Patton, et al. [7]. Creatinine was determined by using Jaffe Colorimetric End point method according to the method described by Schultz, et al. [8] and Heingard, et al. [9] Calcium was determined by Photometric test CPC method according to the procedure described by Houort [10]. The concentration of the inorganic phosphorus in serum sample was determined by the photometric UV Test method described by Gitelman [11]. Serum potassium and sodium was determined by using Electrolytes analyzer [12].

\section{Statistical analysis}

The sero-biochemical data obtained from the blood samples were subjected to standard methods of statistical analysis that was performed using windows-based statistical package for social sciences (SPSS) Version 17.0. Descriptive statistic was used to evaluate the Biochemical parameters in Sudanese donkeys.

\section{Results and Discussion}

The results of the serum biochemical profile and the serum concentration of minerals obtained in this study are given in Table 1. Most data provided from this survey of the literature were in reasonable agreement with the published data for donkeys in other countries, however, there are some differences.

As shown in Table 2, the present results of the serum mean value of creatinine is $(0.070 \pm 0.21) \mathrm{mmol} \backslash \mathrm{L}$ which is falls in the range obtained by Seri, et al. [6] and close to the results of Simenew et al. [13] and Kaneko [15], however, it is slightly different from that obtained by Simenew et al. [13]. The significant differences for creatinine concentrations found, may perhaps reflect the differences in the feeding conditions between different groups of donkeys. Creatinine concentration depends upon the total body content of creatine, which in turn, depends upon dietary intake and muscle mass [14,15]. On the other hand, serum urea concentration is $(13.81 \pm 3.43) \mathrm{mmol} \backslash \mathrm{L}$ which is different from all other studies as presented in Table 2. Meanwhile, serum urea in Sudanese donkeys, Ethiopian and Burkina Faso donkeys are similar. The higher values of urea in our investigation compared to donkeys of other groups could also depend on the components of dietary intake regard to the abundance of nitrogen-containing basic organic Compound in natural pasture, especially proteins as already reported by Kanek et al. [16]. Urea and creatinine generally help in assessing renal damage in animals and humans [17]. The only report for uric acid concentration in donkey was that of Seri et al. [6]. Although his values are slightly lower than ours, this could be comparable with the results obtained in this study. There was no significant variation in the mean values of serum phosphorus concentration across the different groups. Inorganic phosphorus concentration in this study was $1.69 \pm 0.61 \mathrm{mmol} / \mathrm{L}$. Phosphorus is provided by dietary intake, and according to the abundance of this mineral in soil, plants could accumulate it in higher amounts. Therefore, animals which feed on these plants may have higher serum values than their counterparts living in zones with poor phosphorus concentration in the soil and plants [18]. The results obtained in this study for calcium concentration are in agreement with the mean value reported by Seri et al. [6] in the Sudan, AL-Busadah et al. [14] in Saudi Arabia and, [19] in Burkina Faso, but it is higher than that reported by Simenew et al. [13] in Ethiopia. The data obtained in the present study for $\mathrm{Ca}$, and $\mathrm{P}$ was in agreement with the values reported in the literature [20]. Diseases affecting mineral metabolism encompass a wide range of skeletal and soft tissue disorders related to alterations in the homeostasis of calcium $(\mathrm{Ca})$ and phosphorus $(\mathrm{P})$. In equids, these disorders may be broadly grouped as nutritional secondary hyperparathyroidism [21] chronic renal disease [21] primary hyperparathyroidism, [22] pseudohyperparathyroidism [23] and vitamin D toxicosis [24] Serum Sodium in this study was $164.84 \pm 38.88 \mathrm{mmol} \backslash \mathrm{L}$, which is the highest values compared with other investigations in other countries. Dermal losses, burns, Excessive sweating gastrointestinal losses, inadequate water intake are causes of hyper-natraemia. Sustained hyper-natraemia generally occurs when thirst or independent access to water is impaired [25]. On the other hand, potassium concentration in donkey serum are in agreement with findings reported for the Saudi Arabian donkey and Ethiopian donkey. Electrolytes help to maintain the acid-base balance of the body as an increase or decrease in any of them can alter the $\mathrm{pH}$ of the body leading to acidosis or alkalosis [26]. The variations in the serum biochemistry of working donkeys could be due to feeding differences, working conditions and other management factors as well as climatic factors, seasons of study, sample storage mechanism, sample size, working conditions of the animal, techniques of analysis and reagent types [26] With regard to the comparison of results obtained for the (Equus asinus) in the Sudanese breed with other populations (Table 2), we have commented that since the original data from the other breeds and populations are not available, we have not been able to test for statistical differences among populations. We have to constrain ourselves to an approximate interpretation of the comparisons, so these will have to be interpreted with caution.

\begin{tabular}{|l|c|c|c|c|c|c|}
\hline $\begin{array}{l}\text { Parameters } \\
(\mathbf{m m o l} / \mathbf{L})\end{array}$ & Creatinine & Urea & Uric acid & Sodium & Potassium & Calcium \\
\hline Mean values \pm SD & $0.07 \pm 0.21$ & $13.81 \pm 3.43$ & $0.73 \pm 0.53$ & $164.84 \pm 38.88$ & $5.88 \pm 1.95$ & $3.13 \pm 1.09$ \\
\hline
\end{tabular}

Table 1: Mean values \pm s.d Serum biochemical values in donkeys $(n=99)$.

\begin{tabular}{|c|c|c|c|c|c|}
\hline Analyte (mmol/l) & $\begin{array}{l}\text { Sudanese donkey } \\
\text { (Equus asinus) test }\end{array}$ & $\begin{array}{l}\text { Sudanese donkey } \\
\text { (Equus asinus)-1 }\end{array}$ & $\begin{array}{l}\text { Ethiopian donkey } \\
\text { (Equus asinus)-2 }\end{array}$ & $\begin{array}{c}\text { Saudi Arabia } \\
\text { (Hassawi Ass)-3 }\end{array}$ & $\begin{array}{c}\text { Burkina Faso } \\
\text { (Burkinabese)-4 }\end{array}$ \\
\hline Creatinine & $0.070 \pm 0.21$ & $0.094 \pm 0.012$ & $1.098 \pm 0.018$ & $0.110 \pm 0.01$ & $0.101 \pm 22.9$ \\
\hline Urea & $13.81 \pm 3.43$ & $3.20 \pm 1.23$ & $2.63 \pm 0.43$ & $9.18 \pm 1.55$ & $2.38 \pm 0.82$ \\
\hline Uric acid & $0.73 \pm 0.53$ & $0.04 \pm 0.03$ & ----- & ---- & ----- \\
\hline Sodium & $164.84 \pm 38.88$ & $111.28 \pm 11.02$ & $132.92 \pm 5.64$ & $145 \pm 8.0$ & ---- \\
\hline Potassium & $5.88 \pm 1.95$ & $3.96 \pm 0.53$ & $4.51 \pm 0.48$ & $4.8 \pm 0.1$ & --- \\
\hline Calcium & $3.13 \pm 1.09$ & $2.32 \pm 0.30$ & $0.79 \pm 0.22$ & $2.63 \pm 0.15$ & $2.44 \pm 0.51$ \\
\hline Phosphorus & $1.69 \pm 0.61$ & $1.00 \pm 0.23$ & --- & $1.87 \pm 0.11$ & $1.74 \pm 0.83$ \\
\hline References & $\begin{array}{l}\text { Present Results } \\
\text { (Nabaa et al.) }\end{array}$ & [5] & [12] & [13] & [14] \\
\hline
\end{tabular}

Table 2: Comparison of biochemical parameters of Equus asinus donkeys with other donkey breeds, Reference ranges are given as Mean \pm s.d. 
Citation: Al shafei NK, Ahmed SM, Ibrahim AM (2015) Some Sero-biochemical Reference Values of Working Donkeys (Equus asinus) from the Sudan. Biochem Anal Biochem 4: 202. doi:10.4172/2161-1009.1000202

Page 3 of 3

Data in this study and additional studies in other locations, would be highly desirable to can enhance our understanding of biochemical parameters in this species; this data will help in establishing a valuable reference values that would allow veterinarians to establish an appropriate interpretation of laboratory data and give these animals appropriate care.

\section{Acknowledgment}

We are using this opportunity to express my gratitude to Al mansoury Mahady Mustafa for unlimited laboratory work assistance.

\section{References}

1. Roubies N, Panousis N, Fytianou A, Katsoulos PD, Giadinis N, et al. (2006) Effects of age and reproductive stage on certain serum biochemical parameters of Chios sheep under Greek rearing conditions. J Vet Med A Physiol Pathol Clin Med 53: 277-281.

2. Yokus B, Cakir DU, Kanay Z, Gulten T, Uysal E (2006) Effects of seasonal and physiological variations on the serum chemistry, vitamins and thyroid hormone concentrations in sheep. J Vet Med A Physiol Pathol Clin Med 53: 271-276.

3. Etana KM, Jenbere TS, Bojia E, Haileleul N (2011) Determination of Reference Hematological and Serum-Biochemical Values for Working Donkeys of Ethiopia. Veterinary Research 4: 90-94.

4. Botros BAM, Awad AY, Kozman AR, Hildebrandt PK, Maronpot RR (1970) Haematologic blood electrolyte and blood biochemical values of Egyptian domesticated animals. Journal of Egyptian Medical Association 30: 53-61.

5. Lemma A and Moges M (2009) Clinical, hematological and serum biochemical reference values of working donkeys (Equus asinus) owned by transport operators in Addis Ababa, Ethiopia. Livest Res Rural Dev 21: 1-8.

6. Seri HI, Hassan T, Salih MM, Hassan YN (2006) Reference Value on serum Biochemical Parameters of Sudanese Donkey (Equus Asinus) Breed. 12th Sci Cong, Fac Vet Med Assiut Univ, Egypt.

7. Patton CJ, Crouch SR (1977) Spectrophotometric and kinetics investigation of the Berthelot reaction for the determination of ammonia. Anal Chem 49: 464-469.

8. Schultz A and Kaplan A (1984) Uric acid San Diego, Academic Press Inc Chapters 6 and 18, and Appendix VII. Clin Chem the C.V. Mosby Co. St Louis Toronto. Princeton.

9. Heingard, Tiderstrom K (1973) Determination of serum creatinine by direct colorimetric method. Clin Chem Acta 43: 305-310.

10. Houort RL (1985) The estimation of plasma creatinine. Annual Biochem 53 $36-49$
11. Gitelman H (1967) Clinical Chemistry-Calcium-O-Cresolpthalein complexone method: Anal biochemistry 20: 521 .

12. Henry JR (1964) Clinical Chemistry, Harper and Row, Puplisher, New York.

13. Simenew K, Getachew M, Wondyefraw M, Alemayehu L, Eyob L, et al.(2011) Reference Values of Clinically Important physiological, hematological and Serum Biochemical Parameters of Apparently Healthy Working Equids of Ethiopia. Global Veterinary 7: 01-06.

14. AL-Busadah KA, Homeida AM (2005) Some Physical Variables, Biochemica and Haematological Parameters in Hassawi Ass. Scientific Journal of King Faisal University (Basic and Applied Sciences) 6: 1426

15. Kaneko JJ (1989) Clinical Biochemistry of Domestic Animals $4^{\text {th }}($ Edn).

16. Kaneko JJ, Harvey JW, Bruss ML (1997) Clin. biochem. of domestic animals San Diego (Edn).

17. Radostits OM, Blood OC, Gay CC (1994) Veterinanry Medicine, 8th Edn, Bailliere Tindall 1212-1224

18. Calvet H, Friot $D$, Chambon J (1972) Influence des supplementations minérales sur le croît et sur certains témoins biochimiques du métabolisme minéral chez des bovins tropicaux. Revue Elev. Méd. vét. Pays trop 25: 397-408.

19. Sow A, Kalandi KM, Ndiaye NP, Bathily A, Sawadogo GJ (2012) Clinical biochemical parameters of Burkinabese local donkeys' breeds. International Research Journal of Biochemistry and Bioinformatics 2: 84-89.

20. Zinkl JG, Mae D, Guzman MP, Farver TB, Humble JA (1990) Reference ranges and the influence of age and sex on hematologic and serum biochemical values in donkeys (Equus asinus). Am J Vet Res 51: 408-413.

21. Tennant B, Bettleheim P, Kaneko JJ (1982) Paradoxic hypercalcemia and hypophosphatemia associated with chronic renal failure in horses. J Am Vet Med Assoc 180: 630-634

22. Couetil LL, Sojka JE, Nachreiner RF (1998) Primary hypoparathyroidism in a horse. J Vet Intern Med 12: 45-49.

23. Karcher LF, LeNet JL, Turner BF (1990) Pseudohyperparathyroidism in a mare associated with squamous cell carcinoma of the vulva. Cornell Vet 80:153-162.

24. Harrington DD and Page EH (1983) Acute vitamin D3 toxicosis in horses: case reports and experimental studies of the comparative toxicity of vitamins D2 and D3. J Am Vet Med Assoc 182: 1358-1369.

25. Wakil A and Atkin SL (2010) Serum sodium disorders: safe management. Clin Med 10: 79-82.

26. Zinkl J, Mae P, Merida T, Farver, Humble J (1995) Reference range and influence of age and sex on hematological and serum biochemical values in Donkeys, American J Vet Res 51: 408-413. 